\title{
A study on effects of cost-of-equity models on cost-of-capital and capital structure
}

\author{
Meysam Arabzadeh*
}

Accounting \& Management Department, Kashan Branch, Islamic Azad University, Kashan, Iran

\begin{tabular}{|c|c|}
\hline$\overline{A \text { AR T I C L E I N F O }}$ & AB S T R A C T \\
\hline $\begin{array}{l}\text { Article history: } \\
\text { Received March 26, } 2012 \\
\text { Received in Revised form } \\
\text { June, 12, } 2012 \\
\text { Accepted } 19 \text { June } 2012 \\
\text { Available online } \\
\text { June 26 2012 } \\
\text { Keywords: } \\
\text { Size } \\
\text { Financial leverage } \\
\text { Capital structure } \\
\text { Cost of capital } \\
\text { CAPM }\end{array}$ & $\begin{array}{l}\text { Most financial managers believe that there are different factors hindering decision-making } \\
\text { about the capital structure of a company. This hindrance is so that, in some financial } \\
\text { management literatures capital structure is called the mystery of capital. Financial managers } \\
\text { widely believe that financial leverage enjoys a noticeable status in managerial decision making } \\
\text { as well as management of the framework of balance sheet. The primary purpose of this research } \\
\text { is to present applications of equity modules and to study effective factors on such models on } \\
\text { Tehran stock exchange. The study covers data over a period of five years from } 2001 \text { to } 2005 \text {. } \\
\text { The study analyzes and tests relevant data to firm's debt ratio and corporate size as effective } \\
\text { factors on cost-of-equity. The preliminary findings indicate that contrary to the commonly held } \\
\text { belief in financial management theorems, debts ratio has the least effect on cost-of-equity. } \\
\text { Nevertheless, the study suggests that the variant of company's size has a meaningful } \\
\text { relationship with cost-of-equity. To calculate cost-of-equity, CAPM, Gordon and return ratio } \\
\text { methods are used. Findings show that CAPM has more validity compared with other varieties. } \\
\text { On the other hand, the results indicate that there is a 95-percent probability proving that } \\
\text { liquidity has a significant negative effect on financial leverage. }\end{array}$ \\
\hline
\end{tabular}

(C) 2012 Growing Science Ltd. All rights reserved.

\section{Introduction}

The objective of firms' management is to maximize stockholders assets and it has the possibility for taking proper policies and decisions. Implementing assessment models requires estimating company's cost-of-equity. Cost-of-equity means the entire costs of financial units entailing loans interests and the return expected by stockholders reflected as weight average cost of capital (WACC) and it compensates for relevant investment. Cost-of-equity is the cost of using long-term financial resources within a specified period (Fama \& French, 2004). The word equity used in cost-of-equity has a more extended meaning than what it means in accounting. This word not only incorporates stockholders' rights but also includes long-term loans with interests.

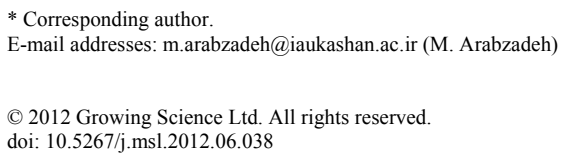


Financial units create value for their stockholders when they earn larger return than the average costof-equity. That is why determining average rate of cost-of-equity is of great significance for financial units. In this regard, the main question here is to understand on how firms should calculate the rate of cost-of-equity. Computing cost of long-term debts is not difficult nevertheless; ambiguity surrounds the case when one wants to calculate the cost for financing a firm by issuing shares.

When we consider the relationship between cost-of-equity and maximizing stockholders' profit, we can to define cost-of-equity in other ways. Cost-of-equity is the minimum return, acquisition of which is necessary for a firm. If a company fails to reach the expected return by stockholders, the share value of that firm will be reduced, consequently. Computing cost-of-equity has always been challenging and difficult.

\section{Review of literature}

During the past few years, there have been much interests among financial managers to study the effect of financial leverage on a firm's cost-of-equity. The main question here is whether a firm could influence its cost-of-equity by diversifying its financial resources. Modigiliani and Miller (1958) are believed to be the first who introduced this subject. After many studies, they came to the conclusion that company's value is independent from its financial leverage (Sinaei \& Nisi, 2003). In economics, capital structure is viewed based on partial equilibrium analysis. This kind of analysis ignores changes in other variables in order to study changes in a variable of its interest. In capital structure, the general tendency is to pay attention to two variables:

- Ko represents company's cost-of-equity,

- Po indicates market price of ordinary shares.

Here the firm's financial leverage as the main variable is analyzed, which means that, the variable keeps major financial decisions including investment policy and shares distribution of the firm. Thus, the main focus is on the study of effects of changes financial composition on share price and cost-ofequity (Sinaei \& Nisi, 2003; Fama, 1998). The following presents various theories proposed by scholars,

- Net operational income theory: Based on this theory a firm's cost-of-equity (Ko) and price of ordinary share (Po) are independent from the firm's financial leverage. In other words, a company's debts regardless of its amount will have no effect on the share price of that company

- Net income theory: Unlike the above theory, net income theory argues that the average cost-ofequity and firm's share price are under the impact of the amount of the financial leverage used. Meanwhile, cost-of-equity is reduced with greater use of debts.

- Traditional Theory: This theory always assumes one ideal structure that can improve company's value. According to this theory, the more company's debts, the less the cost-of-equity. As a result, an increase in the amount of debts will reduce the cost-of-equity and the cost will increase upon a boost in cost of stockholders' rights.

- Modigliani and Miller (1958) rejected the traditional theorem, as they believed any change in the range of financial leverage has no effect on cost-of-equity of a firm. In other words a firm's cost of capital remains constant at various level of financing. Shortly after, Modigliani and Miller made some revision in their theorem to reflect the reduction in cost-of-equity as a result of tax shield to $100 \%$ of financial leverage. Based on their view, cost-of-equity due to increase in financial leverage and tax shield is reduced while arbitrage process will continue. Nevertheless, under such circumstances investor's actions will become under influence of personal tax rate. They asserted that since cost-of-equity increased as a result of an increase in financial leverage, 
leverage firms always worth more than unleveraged firms. In addition, added value will be subject to amount of debt and tax shield

According to Modigliani and Miller (1958), a firm should always seek to increase its financial leverage and they argued on having an optimal level for a firm's financial leverage, which depends on maximum level of debts a firm could raise.

\section{Background for research}

The bulk of research on capital structure is focused on effect of debts and financial leverage on return and firms' value, effects of different industries on capital structure's decisions and we wish to determine factors for financial leverage. Modigliani and Miller investigated to determine whether debts in firms' capital structure have any effects on the firm's value and capital price. They came to the conclusion that debts have positive effect on a firm's value and to a limited degree also affect the average cost-of-equity (Opler \& Titman, 1994; Namazi \& Shirzadeh, 2005).

Fama and French (1992) studied periodical average share return on market risk, firm's size, financial leverage, book value, equity share to market value of stockholders' right and the range of p/e through regression method. They found that market's risk and firm's size have no relationship with average return on share. . On the other hands, the average level of share return have a reverse relationship with book value of financial leverage while having a direct relationship with market value of financial leverage. Fama and French have referred to this relation as a puzzle. Effects of financial leverage on firm's return and corporate value have been studied by other scholars (Bhandar, 1988; Bradley, et al., 1984; Opler \& Titman, 1994). In their studies, they found that financial leverage has affected corporate value. There are some other studies, which determines factors in financial leverage and they indicate that different variables including firm's size, firm's risk class, bankruptcy costs and interest rate impact on rate of using financial leverage. (Namazi \& Shirzadeh, 2005; Opler \& Titman, 1994).

Also in Iran various researches performed on capital structure, for instance, Osmani (2002) in his research studied the relationship between cost-of-equity with the nature of industry, ratio of debts and firms size over the period of five years from 1996 to 2001 on Iran's stock exchange. This study initially introduced five models and then established validity of models by performing tests. In that study, accounting assessment model of EBO had the most validity. It showed that the nature of industry affects cost-of-equity and there was a meaningful relationship between corporate size and cost-of-equity (Fama et al., 1999). Jahanbani and Yazdani (1995) studied the effect of four variables of nature of industry, corporate size, trade risk and degree of operational leverage on using financial leverage in Tehran stock exchange. They used statistical methods of (taking average, standard deviation, multivariable regression, $\mathrm{F}$ test, Dorbin and Watson and co-variance analysis) once for seven combined industry and once for each industry separately. They found that in the combined test nature of industry has effect on financial structure. Nevertheless, corporate size, business risk and financial structure variables had no effect on financial structure. In addition, variables such as corporate size, business risk and operational leverage had no impact on financial structure. In textile industry and household utilities, findings have been somehow different from other industries (Botoson \& Plumlee, 2001). Rahmani (1995) studied the effects of financing (long-term loans, issue of common stock) on share price of firms in stock market using regression model and found that issue of share results in drop in share price. Malekipour (1996) studied the effect of financial leverage on return rate of companies in Tehran stock exchange using correlation coefficient. He concluded that financial leverage has had no effect on return rate of firms under study. Namazi and Parisani (2004) studied the effect of capital structure in companies in Tehran stock exchange on return rate and risk. They divided companies into two groups. Companies that have used credits to finance their operation (in total 46 companies) and companies that have issued new shares to finance their operation (in total 60 companies). Then estimated the return rate on share of first and second groups from 1996 to 2001 
and computed the average total return rate of the two groups. They found that method of financing has a meaningful effect on return rate of shares of companies understudy.

\section{The proposed study}

\subsection{Variables}

\subsubsection{Ratio of Debt to Leverage (LEV $\left.{ }_{i t}\right)$}

Financial leverage set forth in this research is an index of dependent variable and capital structure. Therefore, this variable is calculated by dividing the sum of debts by total assets.

\subsubsection{Cost of equity}

In this research, cost-of-equity as a dependent variable is considered as the main focus of the study. To this end test models this variable was calculated carefully. In addition, cost of financing has been computed.

\subsubsection{Ratio of Illiquidity (ILLIQ $\left.Q_{i t}\right)$}

This ratio is considered as an independent variable and to calculate share liquidity, different variables with their own advantage and disadvantage have been introduced based on economics literature. According to Amihud (2002), the best criterion provided for the calculation of liquidity is as follows:

\subsection{Research hypothesis}

The research studied the relationships of independent variables under study (firm's size and amount of debts) to dependent variables (cost-of-equity) as follows:

- There is a meaningful relationship between financing cost from stockholders' equity and firm's size

- There is a meaningful relationship between financing costs from stockholders' equity and amount of firm's debts

- There is a meaningful relationship among cost-of-equity estimated in different modules.

- there is a significant relationship between share liquidity rate and capital structure of the companies admitted to the stock exchange of Tehran

This research is categorized among positive theories of finance and accounting. Experimental and qualitative evidence were collected and analyzed based on cross-sectional correlation. Conclusion will be based on inductive reasoning.

\subsection{Data collection}

Quantitative data for this research was collected from financial statements of companies accepted in Tehran stock exchange. For the purpose of data collection Tadbir Pardaz Software was used.

\subsection{Sampling procedures}

Samples for the study was collected from among companies in Tehran stock exchange. Selected samples had to satisfy the following criteria:

- Their fiscal period ends at the end of Esfand (i.e. the last month of Persian calendar).

- Their operations in a five-year period resulted in profit/return.

- They have presented the required data for this study to the stock exchange from 2001 to 2005. 
- Companies were involved in manufacturing to increase possibility of samples comparison. Due to different nature of activities investment companies were not selected.

- Selected companies be privately owned and has no relation to governmental institutions.

About 56 sample companies were appointed using accidental sampling.

\subsection{Data analysis}

For the purpose of data analysis, initially cost-of-equity is calculated using three modules. Then they are examined to determine whether modules' results are meaningful. If no meaningful relation established among these modules, one module is selected as a typical. If a meaningful relationship established among the modules it is necessary to select the typical module based on existing logic in financial literature to continue research process. Cost-of-equity calculated in multivariable regression module in question, is considered as dependent variable. Then the effects of independent variables in question including firm's size and relation of debts on the dependent variable is inserted to test different hypotheses. Excel and SPSS software were used to analyze statistics. Before fitting models to study basic hypothesizes relevant to linear modules, equality of variances, modules linearity, normal and independence of models have been established. Durbin and Watson tests as well as correlation efficiency were used. After a series of calculation capital asset pricing model was selected as the most appropriate model. Efficiency of model was reaffirmed using an extra test. In this test Pearson correlation coefficient was calculated to find the amount of cost equity under any of cost equity model with $\beta$ every year. For all sample years correlation coefficient of cost-of-equity was computed based on CAPM module with $\beta$ was higher than cost equity of other models.

\section{The results}

Based on earned calculation, CAPM module has had meaningful relations in three years and thus has confirmed the module. Gordon module in none of the years is meaningful. Realized return rate module only has a meaningful relation in one year. In order to draw a conclusion we should focus on only one module, thus, here meaningful difference in estimating cost-of-equity in different modules using ANOVA. If no meaningful relation is found then one model will be selected and conclusions made based on that model. If there would be a meaningful relation between models then a test should be done for the purpose of selecting a reliable module to reach to a conclusion (if no meaningful relation between modules could be established).

\subsection{Meaningfulness of cost-of-equity in different modules}

The main aim of the present research is to study which one of three modules under study is appropriate for relevant data to Iran stock exchange. In this vein it was necessary from beginning to study whether cost-of-equity under the said three modules are different in 56 sample firms under study or not. In case a meaningful relation be established among them the next step was to relate such modules to the data collected from stock exchange and then to select the best module for such purpose. For such purpose unilateral variance analysis was conducted. Here the main aim of test is to reach $\mathrm{H}_{0}=\mu_{1}=\mu_{2}=\mu_{3}$ against $\mathrm{H}_{1}: \mu_{\mathrm{i}} \neq \mu_{\mathrm{j}}$ (for at least two groups) from 2001-2005. The result derived out of rejection of $\mathrm{H}_{0}$ is that there is a meaningful difference among cost-of-equity modules. When such meaningful difference is established among modules, the methods will be categorized by comparing TUki or Danken.

According F test, we realize that they are larger than the critical F. Thus, Ho hypothesis is rejected (mean level is under 5\%). There is a meaningful difference among estimation methods of cost-of- 
equity in different models. Based on the above conclusion it was tried to fit those into the date collected from 56 sample companies.

\subsection{Selecting the best model of cost-of-equity}

In order to select, the best model for data collected from Iran Stock Exchange, two methods were employed: The first method was linear model of variance analysis as explained earlier. The second method is to estimate the amount of the correlation of cost-of-equity calculated under any of the costof-equity models from 2001 to 2005 as well as $\beta$ during these years.

\subsubsection{Method 1}

Based on research when cost-of-equity under any module has higher correlation with $\beta$ that model would be an acceptable one. With that assumption, the coefficient of Pearson correlation for different years was calculated in order to reach the linear correlation between cost-of-equity under any of costof-equity modules with $\beta$. Findings of this part showed that CAPM for all five years Pearson correlation made meaningful, while cost-of-equity and $\beta$ under this model enjoyed a positive and strong correlation. After this model, the realized return rate model came as an appropriate model. This means that the correlation of cost-of-equity under the model of realized return rate is zero with $\beta$ and thus has correlation together. Finally comes Gordon model.

\subsubsection{Method 2}

In this part, in order to reach a conclusion on fitted regression modules, three methods of estimation was employed in an attempt to choose the most appropriate model for Tehran stock exchange. Different studies proved that again CAPM is the most appropriate one for our purpose. CAPM was confirmed by regression model in 2002, 2003 and 2005 and indicated and confirmed existence of a meaningful relation between dependent and independent variables. CAPM has been confirmed for years 2002, 2003 and 2005 of regression model and established a meaningful relation among independent and dependent variables (in 2005 with R2 more than $16 \%$ at $1 \%$ level), thus, was recognized as the best model for our purpose. At the second and the third respectively come realized return rate model and Gordon model. As Gordon model did not indicate linear relation between independent and dependent variables i.e., statistically the model could not reach a meaning.

\subsection{Specification of best model}

In this section, we present details of analysis of CAPM annually for the average of five years.

5.3.1 Study of a regression model by CAPM method with consideration of a general regression equation (five years mean):

In this part in order to have a general analysis of CAPM module, total regression was calculated and for each five years one regression equation is considered as follows:

\section{Table 1}

Regression coefficients for 2001 -2005 in CAPM module

\begin{tabular}{ccccc}
\hline Predictor & Coefficient & Standard deviation & t-student & P-value \\
\hline Constant & -0.0327000 & 0.1063000 & -0.31 & 0.759 \\
Size & 0.0259970 & 0.0084810 & 3.07 & 0.002 \\
Debt & -0.0008147 & 0.0008757 & -0.93 & 0.353 \\
\hline
\end{tabular}




$$
Y c=-0.033+0.0260 \text { size }-0.000815 \mathrm{debt}
$$

Table 2 presents the results of analysis of variance to study the relationship between cost-of-equity (CAPM) and independent variables (five years mean). As we can observe from the results of Table 1 and 2, the model is acceptable when the level of significance is $1 \%$. If the level of meaningfulness of independent variables is noticed you will see that firm's size has become meaningful with 0.002 and consequently the hypothesis for meaningfulness is confirmed. However, the relationship for debts with mean level of 0.353 had no meaningful value, which indicates that no meaningful relation between debt and cost-of-equity exists.

Table 2

Analysis of Variance

\begin{tabular}{rrrrrr}
\hline Source & Degree of freedom & SS & MS & F & P-value \\
\hline Regression & 2 & 0.32690 & 0.16345 & 4.70 & 0.010 \\
Residual Error & 277 & 9.63623 & 0.03479 & & \\
Total & 279 & 9.96313 & & & \\
\hline
\end{tabular}

\subsubsection{Liquidity: the fourth hypothesis}

In this research, there is a significant relationship between share liquidity rate and capital structure of the companies admitted to the stock exchange of Tehran. To this end, regression equation is considered as follow:

$L E V_{i t}=\alpha_{0}+I L L I Q_{i t}+M / B_{i t}+$ PROFITABILITY $i t+S I Z E_{i t}+T_{A N G}+O W N_{i t}+N D T S_{i t}+P R C_{i t}+$ VOLATILITY

Table 3 provides the results of the regression regarding the hypothesis of this research. Considering the determination coefficient equal to 0.43 , the changes in dependent variable can be based on the changes in independent variables. Moreover, bearing in mind that Durbin-Watson Coefficient is close to 2 , the dependent variable is not correlated. Considering the regression analysis, the dependent variable is in positive relation to illiquidity, growth and tangibility, and in negative relation with other variables. Taking into account that $\mathrm{P}$-value of t-statistic is less than $0.05, \mathrm{H}_{0}$ is rejected, and $\mathrm{H}_{1}$ hypothesis is proved.

Table 3

Regression Results

\begin{tabular}{lccc}
\hline Variable & Coefficient & T-Statistic & P-Value \\
\hline Financial Leverage & -0.65 & -1.53 & 0.000 \\
Illiquidity ratio & 0.14 & 0.59 & 0.000 \\
Growth & 0.24 & 0.89 & 0.01 \\
Profitability percent & -0.71 & -1.78 & 0.000 \\
Tangibility & -0.05 & -1.8 & 0.000 \\
Company's Size & 0.4 & 0.82 & 0.02 \\
Ownership & -0.3 & -1.6 & 0.001 \\
Depreciation percent & -0.41 & -0.95 & 0.04 \\
Price & -0.29 & -1.12 & 0.000 \\
Operating profit risk & -0.12 & -1.15 & 0.03 \\
Determination Coefficient: 0.43 & Adjusted Determination Coefficient: 0.25 & \\
Durbin-Watson: 1.85 & P-Value: 0.000 & & \\
\hline
\end{tabular}




\section{Discussion}

\subsection{Difference of cost-of-equity in various models}

In this research, we studied cost-of-equity using unilateral variance analysis. As a result, it became clear that over the period from 2001, 2003, 2004 and 2005 the level of error stood at 0.05 while in 2002 it was at 0.07 . Thus; it became clear that there has been a meaningful difference between costof-equity models.

\subsection{Validity of cost-of-equity models for stockholder's Equity}

In both methods, it became clear that CAPM model ranked first for validity while the method for rate of realized return come second. Meanwhile Gordon model enjoys less validity when compared to other methods.

\subsection{The effects of corporate size on stockholders' equity}

After establishing reliability and credibility of cost-of-equity models according to the subject of the study, effective factors on cost-of-equity of stockholders' rights were studied. One of these factors that have been identified in the relevant literature is corporate size. Larger companies reasonably have greater access to various financial resources based on their credibility with lesser risk for investment. Naturally the lower the risk the lower will be cost-of-equity. As we may see size factor has become meaningful in residual error of less than one percent; 0.002, thus, our hypothesis concerning existence of a meaningful relation between cost-of-equity and company's size was confirmed. In other word $\mathrm{H}_{1}$ hypothesis is confirmed while $\mathrm{H}_{0}$ hypothesis is rejected.

\subsection{Effect of financial leverage on cost-of-equity of stockholders' equity}

The second factor put to test as effective factor on cost-of-equity was financial leverage. Within finance literature, the relationship between cost-of-equity and financial leverage to certain level leads to reduction of cost-of-equity. From that point, forward this would increase cost-of-equity. In this research, a statistical test was conducted with regard to this hypothesis and in the level meaningfulness for debt is 0.253 . This would indicate that there is no meaningful relation between cost-of-equity and amount of debts in Tehran stock exchange.

\subsection{Effect liquidity on capital structure}

In this research, the illiquidity ratio and debt ratio of the companies admitted to the stock exchange of Tehran are assessed and the effect of liquidity on capital structure is determined. The results of hypothesis test indicate that there is a 95-percent probability proving that liquidity has a significant negative effect on financial leverage. In terms of accounting, this means that any increase in liquidity reduces share capital costs, and financing through share is less expensive than through borrowings. Therefore, according to the hierarchical theories of financing choices, and static trade-off, financing tend to stock market. This achievement is in conformity with the researches of Lipson and Mortal (2004), Udomsirikul et al. (2011). Moreover, the other results obtained from hypothesis test are given in concluding part.

\section{Conclusion}

In this paper, we have presented an empirical study to Tehran Stock Exchange to investigate the behavior of cost-of-equity. Based on the results of this paper we can conclude that there was a meaningful relationship among various models for estimating cost-of-equity, however, CAPM enjoyed greater validity. There was also a meaningful relationship between cost-of-equity and firm's size but cost-of-equity represented no meaningful relationship with firm's debt. The other results are as follows, 
- Growth is in positive relation to financial leverage, which is not in conformity with expected results, since it was assumed that companies with higher growth must has lower leverage.

- Profitability is in a significant negative relation to financial leverage, which is in conformity with expected results, since it was assumed that profitable companies use internal resources more than other ones.

- Company's size is in significant negative relation to financial leverage, which is not in conformity with the expected results, since according to static trade-off theory, it was assumed that larger companies must has lower debt costs. Therefore, borrowing and their financial leverage was expected to be higher.

- Ownership is in significant negative relation to financial leverage, which is in conformity with the expected results, since according signaling theory a negative relation between these two variables was expected.

- Depreciation is in significant negative relation to financial leverage, which is in conformity with the expected results, since according to trade-off theory a negative relation between depreciation and financial leverage was expected.

\section{References}

Arabzadeh, M., \& Maghaminejad, M. (2012). The capital structure and liquidity on the Tehran stock exchange. American Journal of Scientific Research, 47, 69-78.

Amihud, Y. (2002). Illiquidity and stock returns: Cross-section and time series effects. Journal of Financial Markets, 5, 31-56.

Baker, M., \& Wurgler, J. (2002). Market timing and capital structure. Journal of Finance 57, 1-32.

Banz, R.W. (1981). The relationship between return and market value of common stocks. Journal of Financial Economics, 9, 3-18

Bhandar, L.C. (1988). Debt/equity ratio and expected common stock returns: Empirical evidence. Journal of Finance, 43(2), 507-528

Botoson and M. Plumlee, 2001. A Re-examination of Disklosure Level and the Expected Cost of Equity Capital. Working Paper, University of Utah, Salt Lake City, UT.

Bradley, M., Jarrell, G., \& Kim, H. (1984). On the existence of an optimal capital structure: Theory and evidence. Journal of Finance, 3, 857-878.

Deesomsak, R., Paudyal, K., Pescetto, G. (2004). The determinants of capital structure: evidence from the Asia Pacific Region. Journal of Multinational Financial Management, 14, 384-405.

Fama, F. E., \& French, K. (2004). The capital asset pricing model: Theory and evidence. Journal of Economic Perspectives, 18, 25-46.

Fama, E., \& French, K. ( 1992) . The cross-section of expected stock returns. Journal of Finance, 2, 427-460.

Fama, F. E. (1998). Market efficiency, long term returns and behavioral finance. Journal of Financial Economics, 49, 283-306.

Fama, F. E., \& French, K.R. (1999). The corporate cost of capital and retern on corporate investment. Journal of Finance, 54, 1939-1967.

Fischer, E., Heinkel, R., \& Zechner, J. ( 1989). Dynamic capital structure choice: Theory and Test. Journal of Finance, 1, 19-40.

Deesomsak, R., Paudyal, K., Pescetto, G. (2004). The determinants of capital structure: evidence from the Asia Pacific Region. Journal of Multinational Financial Management, 14, 384-405. 
Jahankhani, A. \& Yazdani, N. (1995). The Study of effect of the nature of industry, trade risk and the degree of companies operative leverage on using financial leverage in stock companies. Financial Researches, 17(18), 169-186.

Jensen, M. C., \& Meckting, W.H. (1976), Theory of the firm: Managerial behaviour. Agency costs and ownership structure. Journal of Financial Economics, 305-360.

Lipson, M., \& Mortal, S. (2009). Liquidity and capital structure. Journal of Financial Markets, 611644.

Malekipour Qarbi, M. (1996). Analytical study of using financial lever on profit of TSE companies. M.A Thesis for accounting, Shahid Beheshti University.

Modigiliani, F., \& Miller, M. (1958). The cost of capital, corporation finance and the theory of investment. American Economic Review, 48(3), 261-297.

Myers, S.C. ( 1977). The relationship between real and financial measures of risk and return. Risk and Return in Finance, 1, 49-80.

Namazi \& Shirzadeh (2005), comparing capital structure with profit making of TSE companies (with emphasis on industry). Accounting and accounting, 42, 82-102.

Osmani, M.Q. (2002). Identifying capital costs models and effects of its elements. Ph. D. dissertation, Allameh Tabatabaei University

Opler, T.C., \& Titman, S. (1994). Financial distress and corporate performance. Journal of Finance, 49(3), 1015-1040.

Rahmani, M. (1995). Effects of financing methods (long-term loans \& issuing ordinary share) on companies joined to TSE. M.A thesis in Management, Tehran University

Sinaei \& Nisi (2003). Study of effective elements on the amount of using financial levers in public companies. Accounting studies quarterly, 4 107-121. 